\title{
Genealogy, Ontogeny, and the Narrative Arc of Origins
}

\section{Citation}

Smail, Daniel Lord. 2011. Genealogy, ontogeny, and the narrative arc of origins. French Historical Studies 34(1): 21-35.

\section{Published Version}

doi:10.1215/00161071-2010-020

\section{Permanent link}

http://nrs.harvard.edu/urn-3:HUL.InstRepos:9121283

\section{Terms of Use}

This article was downloaded from Harvard University's DASH repository, and is made available under the terms and conditions applicable to Open Access Policy Articles, as set forth at http:// nrs.harvard.edu/urn-3:HUL.InstRepos:dash.current.terms-of-use\#OAP

\section{Share Your Story}

The Harvard community has made this article openly available.

Please share how this access benefits you. Submit a story.

Accessibility 
Genealogy, Ontogeny, and the Narrative Arc of Origins

Daniel Lord Smail

In the decades around 1900, historians of Europe, the nations of Europe, and European civilization began to fashion a metaphor for the telling of history that followed a narrative arc of recent origins or birth. The field coming to be known as medieval history was, at first, the prime beneficiary of this move. ${ }^{1}$ The narrative arc of origins was at once something venerable and something new. Centuries of universal history written in the Judeo-Christian tradition had described a genealogy of divine origins, where human history, coeval with the history of the earth, was created at a moment of genesis. ${ }^{2}$ The genealogy that ensued was the genealogy of the descendents of Adam. The instinct for genealogy was a labile one, however, and in secular histories it took shape in the genealogy of kings and their battles. ${ }^{3}$ But in the wake of the time revolution of the 1860s, as the very discipline of History was refashioned in the intellectual

${ }^{1}$ For important insights on the national mythologies that gave rise to talk of origins, see Patrick J. Geary, The Myth of Nations: The Medieval Origins of Europe (Princeton: Princeton University Press, 2002).

${ }^{2}$ In general, see Ernst Breisach, Historiography: Ancient, Medieval and Modern, $2^{\text {nd }}$ ed. (Chicago: University of Chicago Press, 1994).

${ }^{3}$ This act of translation from divine to royal genealogy is especially distinctive in French history, given the long-standing custom of viewing the French kings as a succession of "races," one succeeding to the next at fixed dates. Valuable here are the vivid remarks of Alfred Rambaud, in the preface to his two-volume Histoire de la civilisation française, first published in 1885, where he speaks of how he learned history as a child. I consulted the $7^{\text {th }}$ ed. (Paris, 1898). 
ferment that followed upon the publication of Charles Darwin's On the Origin of Species, the metaphors of birth, origins, and creation were removed from the geological and genealogical context of Genesis and gradually put to work in the service of a new ontogeny: the birth and maturation of nations, civilizations, and human institutions. ${ }^{4}$ The doctrine was in keeping with the social evolutionism of the day. It took a long time for the metaphor itself to mature. Although the metaphor of recent birth and origins can be found consistently in works in French across the nineteenth century, it is disconcerting that the first reference to la naissance de la France in the title of a work of history did not appear until 1948, when Ferdinand Lot published a work under

${ }^{4}$ Important studies of the time revolution include Stephen Toulmin and June Goodfield, The Discovery of Time (New York: Harper Row, 1965); Claude Albritton, The Abyss of Time: Changing Conceptions of the Earth's Antiquity after the Sixteenth Century (San Francisco: Freeman, Cooper, 1980); Paolo Rossi, The Dark Abyss of Time: The History of the Earth and the History of Nations from Hooke to Vico, trans. Lydia G. Cochrane (Chicago: University of Chicago Press, 1984), Stephen Jay Gould, Time's Arrow, Time's Cycle: Myth and Metaphor in the Discovery of Geological Time (Cambridge, Mass.: Harvard University Press, 1987); and Thomas R. Trautmann, Lewis Henry Morgan and the Invention of Kinship (Berkeley: University of California Press, 1987), esp. 32-35 and 205-30. Studies of the disciplination of history include Peter Novick, That Noble Dream: The "Objectivity Question” and the American Historical Profession (Cambridge: Cambridge University Press, 1988), and Dorothy Ross, The Origins of American Social Science (Cambridge: Cambridge University Press, 1991). 
this name. ${ }^{5}$ The first important work in English to evoke the birth of Europe in a title, a work written by the medievalist Robert S. Lopez, did not appear until $1962 .^{6}$

The spread of this metaphorical habit, and the pace at which its use has accelerated in recent decades, is an index of the telescoping of historical time. True, a narrative of origins does not entail short histories scrunched into the last few centuries of the human millennia. In the loosely historical models proposed by the thinkers of the Enlightenment, dates of origins are allowed to fade off into the very distant past. The acceptance of deep time as a geological fact following the 1860s suggests origins-histories that could be very deep indeed, as they are in fields like geology, biology, and astronomy. But the narrative of birth or origins that began to spread in the practice of history in the late nineteenth century moved in the other direction. It became a narrative of compression and shortening.

In the later nineteenth century, as the genealogy of Genesis was being shouldered out by the scientific history of nations and their origins, the logic of the new ontogeny demanded a birthdate. It did not make sense for authors to pursue the origins of France or Europe, let alone capitalism and human rights, to the trackless depths of préhistoire—-though some tried. ${ }^{7}$ But

${ }^{5}$ Victor Henri Ferdinand Lot, Naissance de la France (Paris: Fayard, 1948). See the remarks by Carol Symes in this forum. My claim is based on surveys of the Hollis Catalog of the Harvard University Library, the OCLC, and the catalog of the Bibliothèque Nationale de France conducted in August of 2009.

${ }^{6}$ Robert S. Lopez, The Birth of Europe (New York: M. Evans, 1962).

${ }^{7}$ Notably Alfred Rambaud (see below). There is some irony in the fact that French archaeology, in the figures of Édouard Lartet, Jacques Boucher de Crèvecœur de Perthes, and Gabriel de Mortillet, had been instrumental in the fashioning of the very idea of préhistoire. 
once dates of origin are fixed in time by an act of judgment rather than a birth certificate, once histories of things like nations, capitalism, or human rights are mapped out as ontogenies rather than phylogenies, that is to say as the origins of single entities rather than the origins of lineages, the birthdate of the entity is free to wander up and down time's continuum following the whims of authors. Over the course of the twentieth century, even as the time of human and geological history was being extended back further and further, the dates of origins posited by history's ontogeny have drawn inexorably closer to the present day. Once monopolized by medieval historians like Lot and Lopez, it has spread throughout the writing of history. Arguments of origins do not deny a human presence in the time before. But they do, characteristically, flatten out the time before into period of immobility, an era without contour and interest, an era of the eternal standstill.

This paper constitutes a brief inquiry into the growing proclivity for talk of origins over the last century and a half, with special attention to works of history published in French and English. My goal, here, is not to explore trends in the philosophy of history. Instead, I survey the customs of ordinary, practicing historians in the form of the general histories, textbooks, and works of synthesis that they wrote. The inquiry is brief because not easy to know how to assess the presence or weight of origins-talk. Some of the evidence is quantifiable, but the task, ultimately, requires an act of reading and judgment. Hence the value of this, a disciplinary forum, where it is possible to offer preliminary remarks like these in the hopes of generating discussion.

The compression of historical time itself was long in the making, and the rupture induced by talk of origins itself has distant origins, as a brief detour into an earlier age of history-writing 
will suggest. In the late sixth century, as the collective memory of the Germanic invasions was receding and the horror of the Justinianic plague was ebbing away, a Gallo-Roman historian named Gregory set out to record the history of the Frankish people. ${ }^{8}$ Gregory was the bishop of Tours, a week's journey southwest of Paris and outside the pale of direct Frankish settlement and influence in the northern parts of Gaul. The resulting History of the Franks has long been claimed as the first history of France, even though Gregory was scarcely a historian of France. He was a historian of the Franks. The storied lineage of the Frankish kings and queens did not fully satisfy him, however, for he had grander ambitions to write a more universal vein. In his history, therefore, he tells us about the ships that come from the Indies to dock at the Red Sea port of Clysma. He describes the wonders of Constantinople and mentions the Vandal conquest of Mauritania, in Africa. Since universal histories demand a universal time-frame, he began his work at the beginning, with Genesis, and tells us about the Flood, and the generations of Noah, and the story of Moses and the Children of Israel wandering in the deserts of Sinai. Gregory was no innovator. He followed closely on the heels of figures like Origen and Eusebius, who were in turn influenced by the Jewish historian Josephus. ${ }^{9}$ Josephus, who compiled his own histories of the Jews in the wake of Vespasian's conquest of Jerusalem in $70 \mathrm{CE}$, created a chronological scaffolding that allowed sacred history, the history described in the book of Genesis, to be spliced directly onto secular history. The splice remains visible in subsequent histories done in

${ }^{8}$ Gregory of Tours, The History of the Franks, trans. Lewis Thorpe (Harmondsworth: Penguin, 1974).

${ }^{9}$ See Anthony Grafton and Megan Williams, Christianity and the Transformation of the Book: Origen, Eusebius, and the Library of Caesarea (Cambridge, Mass.: Belknap Press of Harvard University Press, 2006). 
this vein. In the case of Gregory of Tours, you can find it right between chapters 16 and 17 of book 1 of the History of the Franks, as Gregory passes from the Hebrew race to talk about the other kingdoms that existed at the time of David and the destruction of the Temple. This is a history and a genealogy that leads up to the Romans and then, by stages, down to the Franks.

Gregory of Tours wrote his history in the comfortable certainty that man and earth were created together in the not-too-distant past, within reach of the genealogical memory that is scripture. History emerges abruptly from Creation, in the white light of full knowledge. Yet there was another possibility, and this was Aristotle's doctrine of earth's eternalism, which held that since something cannot be created from nothing, the earth must be eternal. Eternalism was no idle speculation. Gregory himself was surely acquainted with it, for the historian Orosius, one of Gregory's sources, thought that the belief in eternalism was rampant among the pagan historians of ancient Rome. ${ }^{10}$ Though the doctrine of eternalism, with Aristotle himself, faded from sight in Western Europe, it was revived in the twelfth and thirteenth centuries, only to be condemned by the church in 1215 and 1277 . Yet despite the condemnation, or more likely because of it, eternalism was much fancied in the circles of the natural philosophers of the Italian Renaissance, who were eager to pour scorn on figures like Orosius and the dogma they represented.

${ }^{10}$ Paulus Orosius, The Seven Books of History Against the Pagans, trans. Roy J. Deferrari (Washington: Catholic University of American Press, 1964): "Nearly all men interested in writing, among the Greeks as among the Latins, who have perpetuated in words the accomplishments of kings and peoples for a lasting record ... wish it to be believed in their blind opinion that the origin of the world and the creation of mankind were without beginning." 
As William Connell has recently argued, eternalism, paradoxically, created a profound pessimism with regard to the historian's capacity to write about the first things. ${ }^{11}$ In the model proposed by Niccolò Machiavelli, for example, plagues, famines, and catastrophes regularly wiped clean the slate of memory. The Deluge, Machiavelli wrote, was the most important, "both because it is the most universal and also because those who save themselves are all mountaineers and crude people who, having no knowledge of anything from antiquity, cannot bequeath it to posterity." ${ }^{12}$ So everything back beyond the Deluge is shrouded in the most impenetrable darkness. In a curious way, therefore, the geological doctrine of eternalism, and the certainty of our inability to know those distant times, actually justified the writing of a short history. No moment of creation determines a priori the starting point of one's history, since history can only be written once the historian has confidence in the density of surviving sources - and that is purely a subjective matter. In Gregory's model, History emerged suddenly into the light with Creation. In the model of the Renaissance historians, History merely limps out of the obscuring gloom of fragmented memories and sources.

The claim here appears to be purely epistemological. Yet epistemological claims often serve political interests. In this case, it is important to note that figures like Leonardo Bruni and Machiavelli placed sacred scripture squarely in the darkness of unknown time, since it was uncorroborated by any independent source of evidence. The Deluge had made sure of that,

${ }^{11}$ William J. Connell, "Eternalism vs. Creationism in Renaissance Historiography," paper at the American Historical Association convention, January 2008.

${ }^{12}$ Niccolò Machiavelli, Discourses on Livy, trans. Julia Conaway Bondanella and Peter Bondanella (New York: Oxford University Press, 2003), 169. Cited in Connell, "Eternalism vs. Creationism." 
wiping away all the antiquities and remains of prior civilizations. The shortened chronology, in other words, allowed the non-providential political history favored by the Italian city-states and, later, by national histories, to wriggle free from the grip of sacred history.

Eternalism was the thin edge of a wedge that, over the course of several centuries, gradually separated the short time of particular histories from the deep time of sacred or universal history. Following the publication of On the Origin of Species in 1859, which was soon followed by the other works that made the time revolution, the rift in time suddenly became very deep. Sacred history remained an important genre of history education through the nineteenth century. The multiple nineteenth-century editions or printings of Jacques Bénigne Bossuet's universal history (1679) attest to the lingering influence of sacred history. ${ }^{13}$ But sacred history, since the time of Gregory of Tours, had never been anything more than imperfectly grafted onto secular history and the history of nations. In the wake of the time revolution, Genesis was simply pruned off as an irrelevance to the emerging history of civilization being created by François Guizot (1787-1874) and others. Guizot's Histoire de la civilisation en Europe, as it happens, was published in nearly as many editions as Bossuet's Discours. Not a history per se but rather a set of meditations on the meaning of history and progress, Histoire de la civilisation en Europe is

${ }^{13}$ Jacques Bénigne Bossuet, Discours sur l'histoire universelle (Paris, 1679). During the nineteenth century, the Discours was reiussed, on average, every five years. See also Charles Dreyss, Chronologie universelle (Paris: Hachette, 1853). The fifth edition of this work (1883) continued to affirm a history that began with the creation of the world in $4138 \mathrm{BC}$, the date preferred by some French historians over the date of 4004 BC typically used in the Anglophone world. 
entirely bereft of the framework of sacred history. ${ }^{14}$ Historians of a more secular cast of mind than Guizot produced general histories that began with the Asiatic civilizations or, following Joseph Scaliger, with Egypt. In these works, sacred history was demoted to a history of the Jews, which in turn was typically ranked fourth or fifth on the honor roll of historical precedence. ${ }^{15}$

In many histories of the era, the time revolution is curiously absent. A few lines in some works, philosophical speculations in others, indicate an awareness of the challenge to the chronology of human history. ${ }^{16}$ Yet trauma can be detected in this oblivion. With the collapse of $4004 \mathrm{BC}$ as a secure point of origin, the human sciences now had to contemplate a time that was nigh eternal in its depth. In this way, the time revolution reinstated the geological premise of eternalism that, three centuries earlier, had led Machiavelli to insist upon a shortening of History's ambition and competence. This was not the only source of trauma. Alongside the doctrine of the near-eternity of the earth came the understanding and acceptance of a deep human phylogeny, a concept that was profoundly problematic for the genealogical mode of historywriting. As Nietzsche put it, "in former times people sought to show the feeling of man's greatness by pointing to his divine descent. This, however, has now become a forbidden path, for

${ }^{14}$ Guizot was not lacking in a Christian understanding; noteworthy, therefore, is the fact that he kept the history of Christianity separate from his history of civilization. See the first edition of his Méditations sur l'essence de la religion Chrétienne (Paris: Michel Lévy, 1864), which offers a chronological overview very similar to that offered by Dreyss.

${ }^{15}$ E.g. Lucien Anatole Prévost-Paradol, Essai sur l'histoire universelle, $2^{\text {nd }}$ rev. ed. (Paris: Hachette, 1865).

${ }^{16}$ Doris Goldstein, "Confronting Time: The Oxford School of History and the NonDarwinian Revolution," Storia della Storiografia 45 (2004): 3-27. 
the ape stands at its entrance." ${ }^{\prime 17}$ The problem, for the practice of History, did not lie with Genesis per se. As I have argued elsewhere, the history of Western Civ borrows the basic plot of Genesis, right down to the Mesopotamian origins of civilization around 6,000 years ago. ${ }^{18}$ The problem lay with genealogy, for the practice of writing history as genealogy would lead History backward into what the comte de Buffon had once called the dark abyss of time. ${ }^{19}$ So genealogy had to go.

In its place arose ontogeny and its attendant metaphors of birth, origins, and roots. By virtue of the ontogenetic sleight of hand, the subject of history ceased to be the issue of Adam's body and coalesced instead around a different body, the body of a nation that is born in an act of creation and comes to maturity in its body and its parts. Like the body of the king, it never dies. By the end of the nineteenth century, the shifting nature of origins-talk, in France, is palpable. It took form in the new history of civilization pioneered by figures like Guizot and Duruy and then reworked, in the form of textbooks and works of synthesis, by the scientific history of Gabriel Monod, Ernest Lavisse, and Alfred Rambaud. In a work published in 1882, toward the end of his life, Guizot himself spoke of origins in a strange and strangely moving evocation of the landscape of ancient Gaul two or three thousand years before the present day, where he conjured

${ }^{17}$ Friedrich Nietzsche, The Dawn of Day, trans. J.M. Kennedy (Mineola, N.Y.: Dover Publications, 2007), 53; cited (in a different translation) by Michel Foucault, "Nietzsche, Genealogy, History," in Language, Counter-Memory, Practice: Selected Essays and Interviews, ed. D.F. Bouchard (Ithaca: Cornell University Press, 1977), 143.

${ }^{18}$ Daniel Lord Smail, "In the Grip of Sacred History," American Historical Review 110 (2005): 1337-61.

${ }^{19}$ See Rossi, Dark Abyss. 
up images of limitless swamps, vast forests populated by wolves and bears, frozen rivers, and immense troops of savage pigs, nearly as ferocious as the wolves, who wandered the countryside, responding only to the sound of their guardian's horn. The inhabitants of this land, some six or seven million of them, were rude and lazy (grossiers et oisifs), and did not yet belong to a single nation, bound by the same memories and the same leaders (attachée aux mêmes souvenirs et aux mêmes chefs). ${ }^{20}$ The history he told was a frank history of progress, a history of how these men embarked upon the journey that would lead them to the civilized and Christian land now familiar to all. At its origin (à son origine), he writes, civilization was a thing both difficult and slow to happen. Not even the intelligent merchants of Marseille, of Phocéen rather than Gallic descent, could hope to move things along any faster. ${ }^{21}$

Here, the evocation of the origins of civilization was made in passing, and it is debatable whether Guizot was alluding to anthropological or biblical primitivism. I am inclined to think the latter, for I suspect that Guizot's evocation of Gaul's damp chill would have brought to mind the primitive conditions of the post-diluvial landscape where, as Bossuet had put it two centuries before, all histories begin (tel est le commencement de toutes les Histoires). ${ }^{22}$ Three years later, the model of the Gaulish origins of France was developed more forcefully in Alfred Rambaud's

${ }^{20}$ François Guizot, L'histoire de France depuis les temps les plus reculés jusqu'en 1789 racontée à mes petits-enfants, vol. 1 (Paris: Hachette, 1882), 1-2.

${ }^{21}$ Ibid., 9 .

${ }^{22}$ Bossuet, Discours (1772 ed.), 9. Post-diluvial conditions were not wholly primitive, for Noah's efforts, according to Bossuet, preserved some of the things that man had presumably learned from his Creator in the ante-diluvial days, notably agriculture, the art of pastoralism, clothing, and perhaps (Bossuet isn't sure) the ability to lodge himself. 
history of French civilization (1885). In the preface, he promises to make available to every reader the new history of civilization that is already being taught to girls. ${ }^{23}$ In place of a genealogy of battles, he offers a history of the nation itself, explaining how, "from the multitude of ancient Gaulish tribes or feudal states, was born a nation." ${ }^{24}$ Like Guizot, his history begins in Gaul, though not in a post-diluvial landscape. Instead, he tells us that Gaul will figure more prominently in his history than is usually the case, for we have the blood of the ancient Gauls in our veins. Where Guizot buried the metaphor of origins deep within his first chapter, Rambaud elevated it to the very title of the work-Tome Premier: Les Origines—where it stood out both historiographically and typographically. The first few pages, transcending Gaul itself, speak of primitive times and the "fossil races" who lived in the land that would be France and who left their bones mingled with those of animals long since gone. This is not Guizot's scriptural model, where Gaul springs from a narratival nothingness. Instead, the ancient Gaulois are linked to eras long gone, the eras covered by archaeology, and so the French nation is truly profound.

In pushing deep, Rambaud was following in the footsteps of Victor Duruy's even more profound history, the Abrégé d'histoire générale. ${ }^{25}$ Published in 1873, this is the earliest work of history I have found that admits that history has to begin with the origins of the earth itself. The gesture to geology, admittedly, is not systematic. The first chapter, which in the fashion usual for

${ }^{23}$ Rambaud, Histoire de la civilisation française. In the preface (p. vi), he explains how "le programme adopté dans les lycées de filles met au premier rang l'histoire de la civilisation," presumably because civilization, at the time, was a distinctly feminine subject.

${ }^{24}$ Ibid., vii: comment, de la multitude des anciennes tribus gauloises ou des anciens états féodaux, est née une nation.

${ }^{25}$ Victor Duruy, Abrégé d'histoire générale (Paris: Hachette, 1873). 
the secular histories of the day addressed "Histoire ancienne de l'Orient" - the other option was to begin in Egypt—opens with a section called les origines. "All primitive religions," he tells us, "have tried to explain God, the world, the creation of man and the coexistence, on earth, of good and evil.... Science, in its turn, tries to probe these mysteries, even though the origin of things must ultimately escape it" (1). Thus is initiated a discussion of the genealogy of the earth itself, beginning with the solar system (complete with an allusion to La Place), animal life, and the appearance of man on earth. Duruy writes proudly about the French contribution to the new archaeology. "It was in France that the most numerous discoveries have been made" (3). But those very discoveries have been unnerving. "The first man has thus retreated and is lost in an obscure and terrifying antiquity (une vague et effrayante antiquité)" (4). The grip of Genesis was hard for him to escape, as we see from the question he poses: "Are all humans descended from the same couple?" But it was a felicitous question in one regard, for it allowed Duruy to make a transition into the races of man, thus bringing the narrative back, by stages, to the histories of civilizations, which is where it wanted to be all along. And it was the idea of the races of man, of course, that had inspired Rambaud to speak of the Gauls.

But how workable was this model? In 1893, Rambaud and Lavisse, Duruy's protégés, collaborated in creating a new general history, a mature expression of the scientific history that had been developing in France, as in Germany, for several decades. Executing a typographical boldness that exceeds what Rambaud aspired to in his earlier monograph, the compositor placed the title of the first volume, Les Origines, 395-1095, in the center of an otherwise blank page, announcing in a clarion way the original nature of the claim itself. ${ }^{26}$ What also commands our

${ }^{26}$ Ernest Lavisse and Alfred Rambaud, eds., Histoire générale du IV siècle à nos jours, 12 vols. (Paris: Colin, 1893). 
attention is the chronological leap. Where Guizot had evoked Marseille and hence the CeltoIberian landscape around 600 B.C., where Rambaud's and Duruy's earlier histories had gestured to older epochs, here we find Lavisse and Rambaud taking the fall of ancient civilization as their point of origins. In the imagery deployed by the author responsible for the first chapter, M.A. Bertholet, this was a fecund era, an era that witnessed the formation of the nations of the new Europe ${ }^{27}$ It was fecund because the ideas and habits of the Romans were blended with those of the Germans, a foretaste of the "fusion" metaphor that went on to have such a lively career in the twentieth century. Here, we can see the telescoping of time in action. In less than eight years, roughly a thousand years of historical time were chopped off from the front of history.

A few decades later, as the teaching of Western Civ came to the United States, we see exactly the same progression in the historical philosophy of the American historian James Harvey Robinson, one of the founders of the New History. ${ }^{28}$ Even more than Rambaud, Robinson was inspired by the time revolution, and lobbied for a history that, like Genesis, really would begin at the beginning. But confronted by Machiavelli's problem of receding evidence, he fell back on a fateful compromise. In the wake of the Germanic invasions, as he argued in The Ordeal of Civilization (1926), Western Europe was "nearly completely barbarized." ${ }^{29}$ In this

${ }^{27}$ Ibid., vol. 1, p. 1.

${ }^{28}$ On the teaching of Western Civ, see Gilbert Allardyce, "The Rise and Fall of the Western Civilization Course," American Historical Review 87 (1982): 695-725; Daniel A. Segal "Western Civ and the Staging of History in American Higher Education," American Historical Review 105 (2000): 770-805. I discuss Robinson in On Deep History and the Brain (Berkeley: University of California Press, 2008).

${ }^{29}$ James Harvey Robinson, The Ordeal of Civilization (New York: Harper, 1926), 35. 
way, the conditions of the most primitive times were recreated fifth century. Of course, it was not wholly primitive. The capacity to write was spared. Thanks to this happy exception, we have the sources we need to be able to study European ontogeny.

In recent years, much has been written, from different angles, about the making of medieval studies. ${ }^{30}$ There are heroic accounts that describe how the founders of medieval studies, confronting scholarly and popular prejudices and faced with nearly insurmountable epistemological difficulties, created a proud new discipline. There are postmodern accounts that suggest how medievalists, like anthropologists, were complicitous with the colonial enterprise of the late nineteenth century, and how the victim of this complicity was the period itself. What has been little remarked, however, is how the new ontogeny developing in both France and the United States, fueled by the social evolutionism of the day, created the historical space that justified the study of the European middle ages. In the process, medieval history was itself created, and, in North America at least, James Harvey Robinson was the father of the field.

${ }^{30}$ See, among others, Helen Damico and Joseph B. Zavadil, Medieval Scholarship: Biographical Studies on the Formation of a Discipline, vol. 1, History (New York: Garland, 1995); Kathleen Biddick, The Shock of Medievalism (Durham: Duke University Press, 1998); Gabrielle M. Spiegel, “L'histoire scientifique et les utilisations antimodernistes du passé dans le médiévisme américain," Cahiers du Centre de Recherches Historiques, Réflexions Historiographiques 22 (1999): 87-108; Gabrielle M. Spiegel, "Le projet modernistes des études médiévales: américaniser le Moyen Âge," Cahiers du Centre de Recherches Historiques, Réflexions Historiographiques 22 (1999): 109-29; Kathleen Davis, Periodization and Sovereignty: How Ideas of Feudalism and Secularization Govern the Politics of Time (Philadelphia: University of Pennsylvania Press, 2008). 
Before the 1920s, there were plenty of generalists who studied the feudal age, the age of the seigneurie, the Christian era, and even the middle ages. But it is doubtful that there were many self-described medieval historians. Some measure of this claim is suggested by the fact that the phrase "medieval history" was used in only a scattering of English titles in the later decades of the nineteenth century. Its equivalent, "histoire médiévale," was never used in French history during the nineteenth century, according to title searches I have done. By the 1920s or 1930s, however, in concert with broad trends shaping the discipline as a whole, historians who might have previously thought of themselves as European historians were learning to self-identify as historians of medieval Europe. ${ }^{31}$

As the period of time between the fifth and fifteenth centuries emerged as a legitimate field of inquiry, rather than a Gothic horror show, medieval historians writing in English leapt at the chance to use historical ontogeny and its metaphors of birth, origins, and roots, to claim their period as the point of origin of modernity and its institutions. Since then, metaphors of origin, birth, roots, and revolution have proliferated in medieval historiography, as medieval Europe - in Edward Gibbons' model, a regrettable detour on the path to civilization—-became the period of origin for civil society, the state, commerce and trade, banking, cities, individualism, universities, the modern nuclear family, scientific method, law and justice, human rights,

31 The earliest reference to the phrase "medieval history" in book and chapter titles in the Harvard library collection is from 1889: see Israel Smith Clare, The Unrivaled History of the World, 5 vols. (Cleveland: Burrows, 1889), which entitles the third volume "Medieval History." Histories of a period called "the Middle Ages" date back to earlier decades, one of the first being Sharon Turner, The History of England during the Middle Ages (London: Longman, Hurst, Rees, Orme, Brown and Green, 1825). 
citizenship, colonialism, fashion, and more recently, even persecution. ${ }^{32}$ The point was clear: the claim of medieval origins justified the inclusion of medieval Europe in the history curriculum.

${ }^{32}$ A cursory sampling follows, in date order. The titles listed below include important works that use origins-talk in titles and also several that do not but are nonetheless, in my view, characterized by an ontogenetic framework. Charles Homer Haskins, The Rise of Universities (New York: Holt, 1923); Lynn Thorndike, A History of Magic and Experimental Science (New York: Macmillan, 1923-1958); Paul Post, "La naissance du costume masculin modern au XIVe siècle," Actes du $1^{\text {er }}$ Congrès international d'histoire du costume (Venice: Centro internazionale delle arti e del costume, 1955) (proposed the idea of a "clothing revolution"); Joseph Reese Strayer, On the Medieval Origins of the Modern State (Princeton: Princeton University Press, 1970); Robert S. Lopez, The Commercial Revolution of the Middle Ages (Englewood Cliffs: Prentice-Hall, 1971); Colin Morris, The Discovery of the Individual, 1050-1200 (New York: Harper Row, 1972); Alan Macfarlane, The Origins of English Individualism: The Family, Property and Social Transition (Oxford: Blackwell, 1978); C. Stephen Jaeger, The Origins of Courtliness: Civilizing Trends and the Formation of Courtly Ideals, 939-1210 (Philadelphia: University of Pennsylvania Press, 1985); R.I. Moore, The Formation of a Persecuting Society: Power and Deviance in Western Europe, 950-1250 (Oxford: Blackwell, 1987); Robert Bartlett, The Making of Europe: Conquest, Colonization, and Cultural Change, 950-1350 (Princeton: Princeton University Press, 1993); William D. Phillips, The Medieval Origins of European Expansion (Minneapolis, 1996); Julius Kirshner, ed., The Origins of the State in Italy, 1300-1600 (Chicago: University of Chicago Press, 1996); Brian Tierney, The Idea of Natural Rights: Studies on Natural Rights, Natural Law and Church Law 1150-1625 (Atlanta: Scholars Press, 1997) (proposes the idea of the medieval origins of natural rights); Maurizio Lupoi, The Origins 
These titles, in turn, have iconic status as some of the foundational texts in medieval history, and are rightly included as required reading on many a graduate exam list.

(Insert Graph 1 around here)

of the European Legal Order, trans. Adrian Belton (Cambridge: Cambrige University Press, 2000); Keechang Kin, Aliens in Medieval Law: The Origins of Modern Citizenship (Cambridge: Cambridge University Press, 2000); Michael McCormick, The Origins of the European Economy: Communications and Commerce A.D. 300-900 (Cambridge: Cambridge University Press, 2001); James A. Brundage, The Medieval Origins of the Legal Profession: Canonists, Civilians, and Courts (Chicago: University of Chicago Press, 2008). 
Graph 1: Talk of Origins in Works of Medieval History, 1800-2009

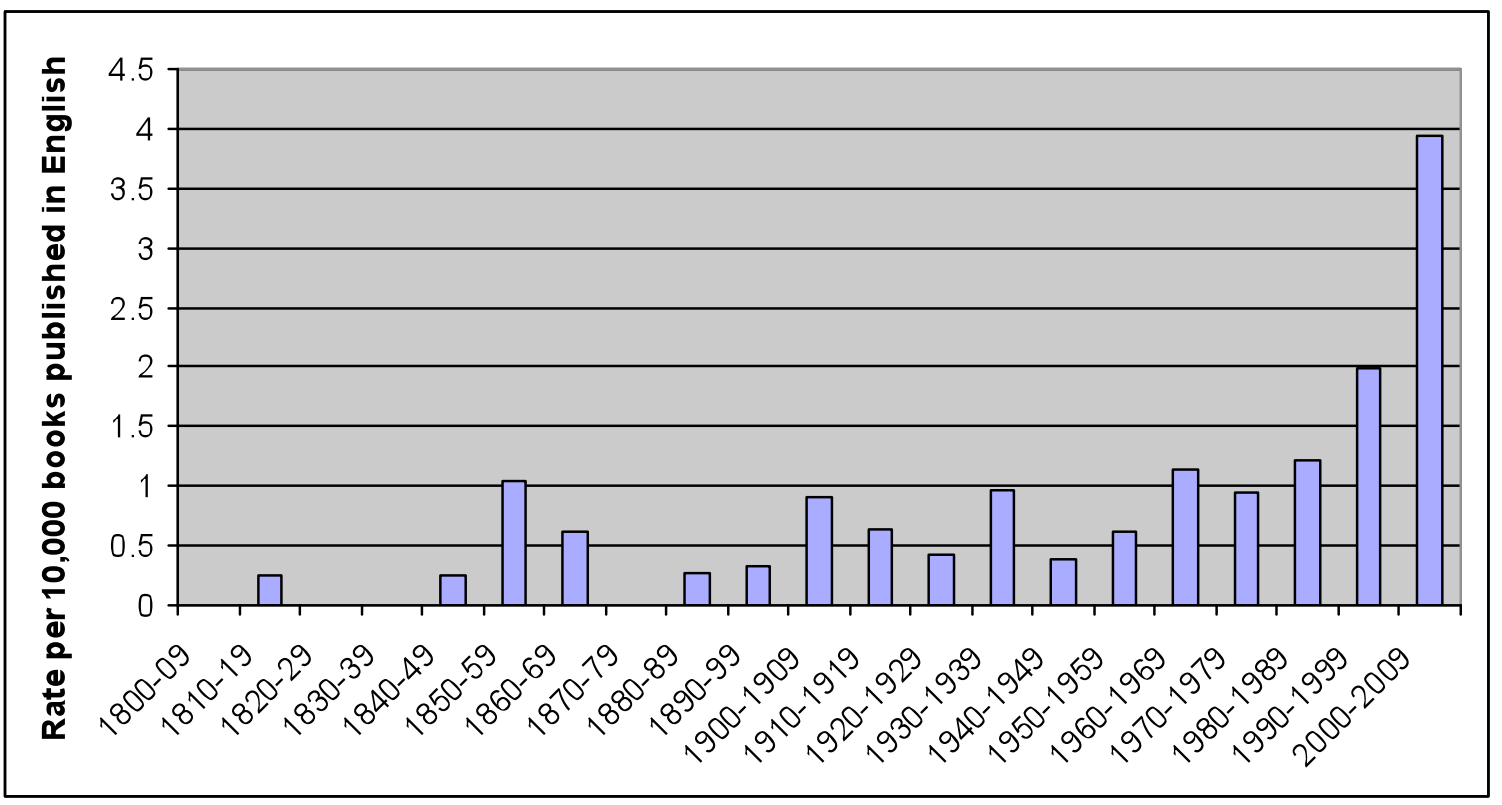

(Explanation: Books catalogued in Hollis, the on-line catalog of the Harvard University Library system. Search limited to books published in English with the following search terms: su="medieval or mediaeval or middle ages " AND ti="birth or origin or origins or roots." The Hollis catalog includes chapter titles as well as book titles in the title search.

Results are then expressed, per decade, relative to the total number of books published in English and catalogued in Hollis, at a rate of 1 per 10,000.)

The French case is different. The pedigree of origins-talk, after all, takes us back to the discourse of the Enlightenment, and the makers of the French Revolution were conscious of their role as inaugurators of a new world. The novelty of the late nineteenth century did not consist of developing origins-talk from scratch; rather, as we saw in the case of Rambaud and Lavisse, it was a question of applying it systematically to the origins of France in the middle ages. The expression l'histoire médiévale is vanishingly rare in French before the middle of the twentieth century. By the 1930s, however, under the influence of Henri Pirenne's great thesis tracing the origins of medieval civilization to the rise of Islam, it became common in French historiography 
to posit medieval origins for Europe. ${ }^{33}$ This is what made l'histoire médiévale thinkable, and thus prepared the groundwork that created the possibility, in 1949, for the idea of la naissance de la France.

In the early decades of the twentieth century, there was, it seems, a consensus: though talk of origins could be found everywhere, it was especially attractive to the new medieval scholarship, whether the resolution was broad and embraced whole nations or whether the resolution was narrow and targeted areas like the economy, bureaucracy, or the law. Since then, one of the most distinctive trends in history writing in the twentieth century has been the loss of what I have suggested was once a medieval monopoly on origins talk. We can begin to measure this simply by noting how use of origins talk has become more prevalent in all fields of European history since the 1960s.

${ }^{33}$ Henri Pirenne, Villes du Moyen Âge, essai d'histoire économique et sociale (Brussels: Lamertin, 1927; trans. Frank D. Halsey, Medieval Cities: Their Origins and the Revival of Trade [Princeton: Princeton University Press, 1939]); Henri Pirenne, Mahomet et Charlemagne (Paris: Club des libraires de France, 1937; trans. Bernard Miall, Mohammed and Charlemagne [New York: Norton, 1939)]; Raymond de Roover, “Aux origines d'une technique intellectuelle: la formation et l'expansion de la comptabilité à partie double," Annales d'Histoire économique et social 9 (1937): 171-93, 270-97; Robert Latouche, Les origines de l'économie occidentale, IVeXIe siècle (Paris: A. Michel, 1956); Robert Fossier, Enfance de l'Europe Xe-XIIe siècle: aspects économiques et sociaux (Paris, Presses universitaires de France, 1982); Jacques Le Goff, Europe est-elle née au Moyen Âge? Essai (Paris: Seuil, 2003; trans. Janet Lloyd, The Birth of Europe [Oxford: Blackwell, 2005]). For a discussion of the Pirenne debate, see Bryce Lyon, The Origins of the Middle Ages: Pirenne's Challenge to Gibbon (New York: Norton, 1972). 
(Insert Graph 2 around here)

Graph 2: Frequency of Origins Talk in European Historiography, 1900-2009

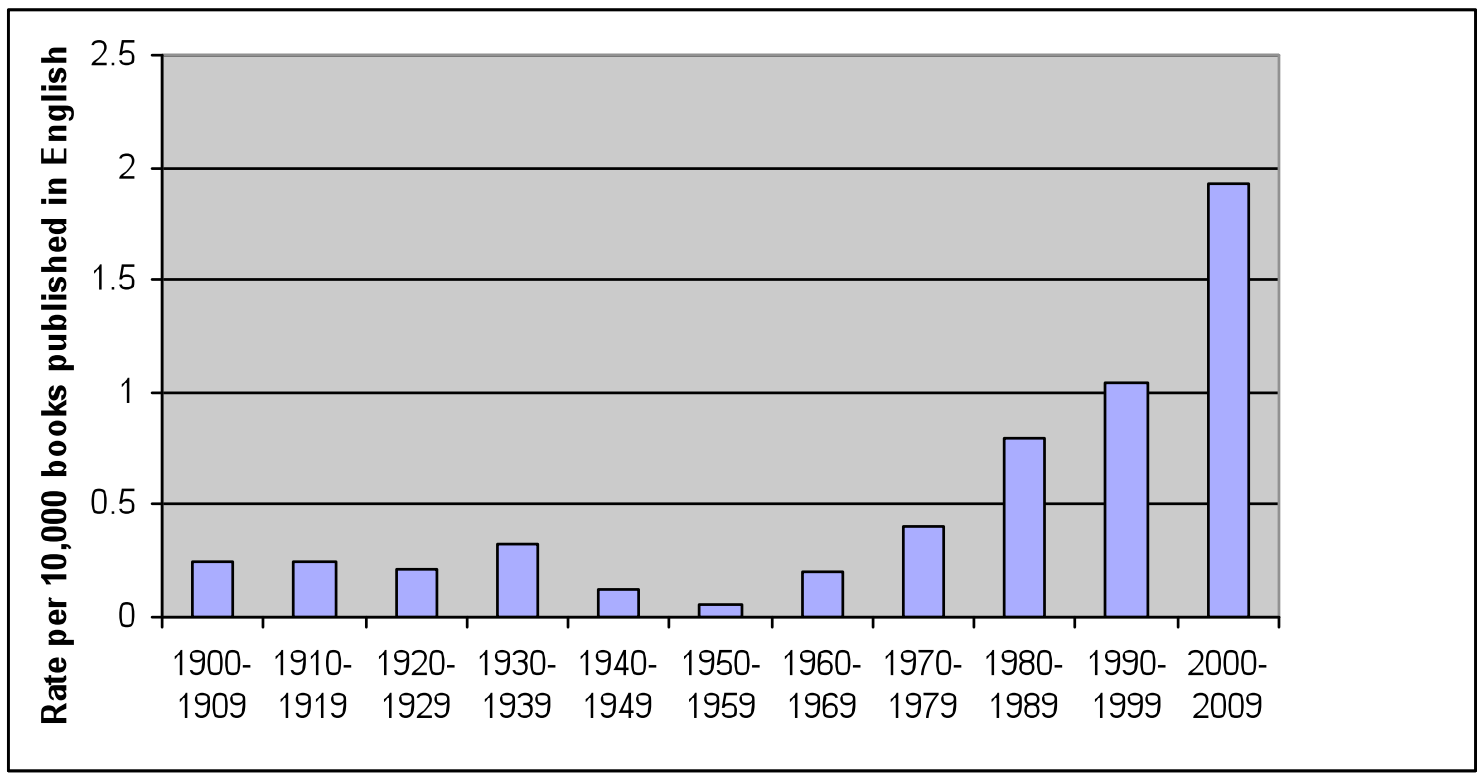

(Explanation: For general parameters, see Graph 1. Search limited to books published in English with the following search terms: su="history and europe" AND ti="birth or origin or origins or roots." Relative to the total number of books published in English and catalogued in Hollis, at a rate of 1 per 10,000. The nineteenth-century data are not especially meaningful since the subject heading "History-Europe" is not commonly applied to works of the nineteenth century.)

In this literature, claims of postmedieval origins have become legion, ranging from the discovery of Renaissance self-fashioning and the emergence of the eighteenth-century public sphere to the shift to a two-sex model of human sexuality and the birth of the modern world 
system. ${ }^{34}$ Granted, the metaphors are sometimes deployed in casual ways. They appear in titles or introductions but do not suffuse the substance of arguments. In other works, though, the use of the metaphor is more thorough-going. In these cases, the narrative arc presupposes a shift from

${ }^{34}$ Much of this literature was inspired, directly or indirectly, by Karl Polanyi, The Great Transformation (New York: Rinehart, 1944). Metaphors of revolution and transformation are not necessarily metaphors of birth and origin, though Polanyi's use of "transformation" certainly operated in an ontogenetic way, and a later edition of the book (Boston: Beacon Press, 2001) was subtitled "The Political and Economic Origins of Our Time." Arguments of origin typically evoke scalar leaps, e.g. in population, energy consumption, industry (e.g. print capitalism), and the effect of such arguments is to flatten out the history before the leap. Some especially significant works in recent decades include Immanuel M. Wallerstein, The Modern WorldSystem: Capitalist Agriculture and the Origins of the European World-Economy in the Sixteenth Century (New York: Academic Press, 1974); Stephen Greenblatt, Renaissance Self-Fashiniong: From More to Shakespeare (Chicago: University of Chicago Press, 1980); Jürgen Habermas, The Structural Transformation of the Public Sphere: An Inquiry into a Category of Bourgeois Society, trans. Thomas Burger with the assistance of Frederick Lawrence (Cambridge: MIT Press, 1989): Thomas Laqueur, Making Sex: Body and Gender from the Greeks to Freud (Cambridge, Mass.: Harvard University Press, 1990); Kenneth Pomeranz, The Great Divergence: China, Europe, and the Making of the Modern World Economy (Princeton: Princeton University Press, 2000); Christopher A. Bayly, The Birth of the Modern World, 17801914: Global Connections and Comparisons (Oxford: Blackwell, 2003); Lynn Hunt, Inventing Human Rights: A History (New York: Norton, 2007); Gregory Clark, A Farewell to Alms: A Brief Economic History of the World (Princeton: Princeton University Press, 2007). 
stasis to movement, a leap in scale or complexity followed by a dizzying ascent, the very figure of what some have called the j-curve of modernity.

The feature common to all these arguments of birth and origins is their tendency to flatten out the time before. As Paul Strohm has noted, the "Middle Ages are debunked as static, hieratic, and unchanging. $" 35$ The dismissive gestures that Strohm has noted in literary fields are not hard to find in works of history, in the gestures to the medieval "void," or "traditional" society. The static condition is what Leopold von Ranke had once called "the eternal standstill." In making this infamous observation, Ranke had been contemplating the civilizations of the orient, and commenting on what he believed to be their eternal, non-progressive cycling. It is a curious feature of historical practice in the last two or three decades that, even as historicity has been rightly restored to East Asia, to Africa, and to all the people without history, it is now being denied to the European middle ages. Historicity, it seems, is a zero-sum game. There is only so much of it to pass around, and for some to have it, others must do without. In this way, medieval Europe has become History's prehistory. The savage Gaulish landscape once imagined by Guizot, with its limitless swamps, forests, and frozen rivers, the wolves and bears and savage pigs, now endures to 1500 and beyond, with scarcely a single Phocéen beacon to lighten the gloom.

Is there anything intrinsically wrong with talk of origins? Looked at one way, the answer is clearly no. Some of the works we most admire today are exactly those whose authors have the vision, and the wherewithal, to make a powerful claim of origins. To the extent that they are measurable, moreover, these claims turn out to be true. The graphs illustrating such things as

${ }^{35}$ Paul Strohm, Theory and the Premodern Text (Minneapolis: University of Minnesota Press, 2000), 158; cited in Holsinger, The Postmodern Condition, 13. 
population growth, energy consumption, deforestation, and global temperatue all take a noticeable bend in the nineteenth or twentieth centuries. We are awash in a sea of goods that did not exist, in quite this way, five centuries ago, let alone five millennia ago. A fine new book on the history of readers in France provides convincing statistics regarding escalating print runs. ${ }^{36}$ It would be foolish or invidious to challenge the basic truths on which some narratives of origin are founded. The point here is that evocations of birth or origins, perhaps inevitably, perhaps unintentionally, lead to a flattening of history and a compression of historical time. To postulate a leap or a rupture is to flatten everything that came before into an uninteresting prehistory and stifle historical curiosity in the Great Before. In such models, the time of history is compressed into the narrow space of the Everything After.

A telescoping of historical time has been underway for over a century, ever since the time revolution confronted historians with the fact of a nearly ageless earth. Where the practice of history is concerned, the result of the time revolution was the fragmentation of the human past into a prehistorical period and a historical period. The new history demanded a new narrative, hence the emergence of ontogeny, with its metaphors of birth and origins. As I have tried to suggest in this paper, ontogeny is not intrinsic to the practice of history. The metaphor made its way into History only at the moment when historians, contemplating the obscure and terrifying antiquity that had alarmed Duruy, turned to the lycées des filles and other sources of inspiration for a history of civilization and of nation that could obviate the need to explore the trackless depths of prehistory. But once history was released from the duty to trace a genealogy back as far

\footnotetext{
${ }^{36}$ Martyn Lyons, Reading Culture and Writing Practices in Nineteenth-Century France
} (Toronto: University of Toronto Press, 2008). 
as the evidence can take us, once historians were given the discretionary power to determine when a static prehistory gives way to an active history, then the moment of creation became a moveable feast, free to wander up time's continuum, in hot pursuit of the powerful myth that is modernity. And so our histories have, for now, ceased to be history, and have become, instead, mythology. 